Original Research Article

\title{
Comparative study of analgesic effect of Moringa oleifera leaf extracts with aspirin on experimental animals
}

\author{
Prashanth Kumar Patnaik $^{1}$, Mohammed Abdul Majeed ${ }^{1 *}$, Bhuvaneshwari², \\ Laksmi Kameswari $^{3}$, M. B. Niharika ${ }^{1}$
}

${ }^{1}$ Department of Pharmacology, Mahavir Institute of Medical Sciences, Vikarabad, Telangana, India

${ }^{2}$ Department of Pharmacology, Osmania Medical College, Hyderabad, Telangana, India ${ }^{3}$ Department of Pharmacology, RIMS, Nizamabad, Telangana, India

Received: 24 August 2018

Revised: 22 September 2018

Accepted: 26 September 2018

*Correspondence to:

Dr. Mohammed Abdul Majeed, Email: drmamajeed@yahoo.com

Copyright: (C) the author(s), publisher and licensee Medip Academy. This is an openaccess article distributed under the terms of the Creative Commons Attribution NonCommercial License, which permits unrestricted noncommercial use, distribution, and reproduction in any medium, provided the original work is properly cited.

\begin{abstract}
Background: Moringa oleifera is highly valued with a wide range of medicinal uses. It is abundantly available in tropical and sub-tropical countries. It has been used as an analgesic and anti-inflammatory in Indian folk medicine since centuries. The mechanism of action of analgesic effect is by the phytochemical components of its leaves which contain alkaloids, glycosides, phenols, saponins and tannin.

Methods: This experiment is carried out in mice by using the thermal method of analgesiometer, that is Eddy's Hot Plate method. Thermostatically controlled electrically heated plate is used in this method. Ethanolic and aqueous extracts of Moringa oleifera leaf extracts are compared with aspirin.

Results: When the analgesic properties of the standard drug aspirin were compared to the analgesic properties of ethanolic and aqueous extracts of Moringa oleifera, the ethanolic extract showed a comparable analgesic effect with aspirin at $90 \mathrm{~min}$. Among these two extracts, the ethanolic extract showed a higher response than aqueous extract.

Conclusions: When the analgesic properties of the standard drug aspirin were compared to the analgesic properties of ethanolic and aqueous extracts of Moringa oleifera, the ethanolic extract showed a comparable analgesic effect with aspirin at $90 \mathrm{~min}$. Among these two extracts, the ethanolic extract showed a higher response than aqueous extract.
\end{abstract}

Keywords: Aqueous extract of Moringa oleifera, Analgesics, Eddy's hot plate method, Ethanolic extract of Moringa oleifera, Moringa oleifera

\section{INTRODUCTION}

Pain is a distressing feeling to an intense or damaging stimulus. The sensation of pain is as old as human. As it is a subjective phenomenon it's definition is really a challenge. Definition of pain put forward by The International Association for the study of pain is "An unpleasant sensory and emotional experience associated with actual or potential tissue damage or described in terms of such damage". ${ }^{1}$ The use of NSAIDs is still the mainstay of treating pain, despite their commonly known side effects like gastrointestinal, renal and other adverse actions which are due to their non-selective action.

For centuries, natural analgesic compounds have been used to mediate the pain process, and often with fewer side 
effects. One such example having these analgesic compounds is Moringa oleifera.

Moringa oleifera is highly valued with a wide range of medicinal uses. It is abundantly available in tropical and sub-tropical countries. It has been used as an analgesic and anti-inflammatory in Indian folk medicine since centuries. The mechanism of action of analgesic effect is by the phytochemical components of its leaves which contain alkaloids, glycosides, phenols, saponins and tannin. The analgesic effect is due to the inhibition of the activity of cox-2 (cyclooxygenase-2) which in turn inhibits the synthesis of prostaglandins. ${ }^{2}$ In the present study, the analgesic property of Moringa oleifera leaf extracts has been compared with a standard drug-aspirin, in animals by adopting Eddy's hot plate method.

\section{METHODS}

\section{ANIMALS:}

In the present study, Albino mice of either sex, weighing 20-25 gm were selected. 24 mice were procured from Central Animal House, Osmania Medical College Hyderabad, Telangana, India.

\section{Chemicals}

- $\quad$ Aspirin (ASICOM-75mg was obtained from Comed Chemicals Private Limited),

- Aqueous extract of Moringa oleifera,

- Alcohol extract of Moringa oleifera.

\section{Preparation of Moringa oleifera extracts}

For this study, leaf extracts of Moringa were used. First the leaf powder was purchased from a reliable and authentic company-Paraman Food works (Food Safety and Standards Authority of India (FSSAI) Reg No.
22413409000104 and ISO 9001:2008 registered). By using Soxhalet's_apparatus extracts were prepared.

\section{Experimental design}

All the drugs in this study were given orally. Dose of the standard was interpreted from the equivalent dose. ${ }^{3}$ The doses of Moringa oleifera extracts in mice to produce adequate desired effect from various studies are taken as $100 \mathrm{mg} / \mathrm{kg} .{ }^{4}$ In previous studies toxicity tests were done and concluded that the doses up to $2000 \mathrm{mg} / \mathrm{kg}$ were safe. ${ }^{5}$

\section{Evaluation of analgesic property}

Twenty-four Albino mice of either sex, weighing 2030 gram were selected for the experiment, and divided into 4 equal groups. To the mice of control group distilled water was given, for the standard group mice aspirin at the dose of $35 \mathrm{mg} / \mathrm{kg}$ was given. And for the test groups, aqueous and ethanolic extracts were given at $100 \mathrm{mg} / \mathrm{kg}$ dose.

They are then placed on the hot plate through the upper lid. Paws of mice are very sensitive to the temperature. Responses like jumping, withdrawal of the paws and licking of the paws were observed. By using a stop watch, reaction time for these responses to occur were noted. The animals were tested, and results were noted at 0, 30,60 and $90 \mathrm{~min}$. A constant temperature of $55^{\circ} \mathrm{C}$ was maintained throughout the experiment. And the cut off time to prevent damage to the paws was $15 \mathrm{sec}$.

\section{RESULTS}

The effects of drugs on mice were observed and recorded as follows. Analgesic activity of the drugs was based on increase in the mean reaction times to the response for a noxious stimulus. Behavioural components like paw licking, jumping are observed as a response to the noxious stimulus (hot plate) in terms of their reaction times.

Table 1: Mean reaction times expressed as mean \pm standard deviation of different groups, at different time intervals.

\begin{tabular}{|lllllll|}
\hline $\begin{array}{l}\text { Time in } \\
\text { min. }\end{array}$ & Control & $\begin{array}{l}\text { Standard } \\
\text { (Aspirin) }\end{array}$ & $\begin{array}{l}\text { Aqueous extract } \\
\text { (Test 1) }\end{array}$ & $\begin{array}{l}\text { Ethanolic } \\
\text { extract (Test 2) }\end{array}$ & S value* & Significance \\
\hline 0 & $3.03 \pm 0.22$ & $2.98 \pm 0.43$ & $3.03 \pm 0.27$ & $3.00 \pm 0.17$ & 0.293 & NS, $>0.05$ \\
\hline 30 & $3.03 \pm 0.20$ & $6.98 \pm 0.46$ & $5.61 \pm 0.23$ & $5.86 \pm 0.22$ & 0.298 & $\mathrm{~S}, \mathrm{p}<0.05$ \\
\hline 60 & $2.91 \pm 0.39$ & $8.12 \pm 0.55$ & $6.25 \pm 0.19$ & $6.86 \pm 0.36$ & 0.396 & $\mathrm{~S}, \mathrm{p}<0.05$ \\
\hline 90 & $2.96 \pm 0.54$ & $9.91 \pm 0.17$ & $7.10 \pm 0.37$ & $7.91 \pm 0.15$ & 0.345 & $\mathrm{~S}, \mathrm{p}<0.05$ \\
\hline
\end{tabular}

*S value calculated using One-way ANOVA, S- significant, NS- not significant

\section{At zero minute}

In this result, the null hypothesis states that, the mice will not show any response to the stimuli at zero minute. $\mathrm{S}$ value indicates that the standard deviation between the data points and the fitted values is approximately
0.293 units. The p-value is above than the significance level of 0.05 , this clearly depicts that null hypothesis can't be rejected and it can be concluded that there is no difference in the mean of four groups. 


\section{At thirty minutes}

In this result, the null hypothesis states that the mice will not show any response to the stimuli at thirty minutes. S indicates that the standard deviation between the data points and the fitted values is approximately 0.298 units. The $p$-value is very less than the significance level of 0.05 , this clearly depicts that null hypothesis can be rejected and it can be concluded that there is a significant difference in the mean of four groups.

\section{At sixty minutes}

In this result, the null hypothesis states that the mice will not show any response to the stimuli at sixty minutes. S indicates that the standard deviation between the data points and the fitted values is approximately 0.396 units, which is more than the results obtained at zero and thirty minutes. The $\mathrm{p}$-value, which is less than the significance level of 0.05 , this clearly depicts that null hypothesis can be rejected and it can be concluded that there exists a significant difference in the mean of four groups.

Table 2: $P$ values and statistical significance on comparison of reaction times between different groups using Dunnett's test.

\begin{tabular}{|lllll|}
\hline Groups & $\begin{array}{l}\text { Time } \\
\text { Intervals }\end{array}$ & t value & $\mathbf{P}<\mathbf{0 . 0 5 *}$ & Sig. \\
\hline & 30 & 6.52 & Yes & $\mathrm{S}$ \\
\hline $\begin{array}{l}\text { Standard vs } \\
\text { Test 1 }\end{array}$ & 60 & 7.87 & Yes & $\mathrm{S}$ \\
\cline { 2 - 5 } & 90 & 6.90 & Yes & $\mathrm{S}$ \\
\hline & 30 & 5.38 & Yes & $\mathrm{S}$ \\
\hline & & & & \\
\hline $\begin{array}{l}\text { Standard } \\
\text { vs Test 2 }\end{array}$ & 60 & 4.69 & Yes & $\mathrm{S}$ \\
\hline & 90 & 21.60 & Yes & $\mathrm{S}$ \\
\hline & 30 & 1.92 & No & $\mathrm{NS}$ \\
\hline & & & & \\
\hline $\begin{array}{l}\text { Test 1 vs } \\
\text { Test 2 }\end{array}$ & 60 & 3.67 & Yes & $\mathrm{S}$ \\
\hline & & & & \\
\hline & 90 & 4.96 & Yes & $\mathrm{S}$ \\
\hline
\end{tabular}

\section{At ninety minutes}

In this result, the null hypothesis states that the mice will not show any response to the stimuli at ninety minutes. $\mathrm{S}$ indicates that the standard deviation between the data points and the fitted values is approximately 0.345 units. The p-value, which is less than the significance level of 0.05 , this clearly depicts that null hypothesis can be rejected and it can be concluded that there is a significant difference in the mean of four groups.

From the observations of ANOVA, it is understood that, when compared to control group, the standard and test groups showed significant $(\mathrm{p}<0.05)$ increase in the mean reaction time. This indicates that the standard, ethanolic and aqueous extracts of Moringa have analgesic property.

In Table 2, standard, ethanolic and aqueous groups were compared with each other. In this table, $\mathrm{P}$ values and statistical significance on comparison of reaction times between different groups using Dunnett's multiple comparison test were done.

When the standard group was compared with the aqueous group (test 1), it was found to be significantly better $(\mathrm{p}<0.05)$ at 30,60 and 90min. It indicates that, even though the aqueous extract, has analgesic property, it is not as effective as the standard drug at this dose.

When the standard group was compared with the ethanol group (test 2), it was found to be significantly better $(\mathrm{p}<0.05)$ at 30, 60 and 90min. Ethanolic group showed almost similar response like standard group but not as effective as standard.

When test 1 and test 2 are compared with each other, there was no significant difference $(p>0.05)$ between the two groups at $30 \mathrm{~min}$, indicating that ethanolic and aqueous groups were equally effective at $30 \mathrm{~min}$. At $60 \mathrm{~min}$ and $90 \mathrm{~min}$ there was a significant difference $(\mathrm{p}<0.05)$ between the ethanol and aqueous test groups.

And at 90min, the ethanolic extract group showed a maximum percentage increase in mean reaction time, which is almost near to the standard drug. However, since the observation period in this study was only $90 \mathrm{~min}$ we could not make any comment on the further course of action of these extracts.

When the analgesic properties of the standard drug aspirin were compared to the analgesic properties of ethanolic and aqueous extracts of Moringa oleifera, the ethanolic extract showed a comparable analgesic effect with aspirin at 90min. Among these two extracts, the ethanolic extract showed a higher response than aqueous extract.

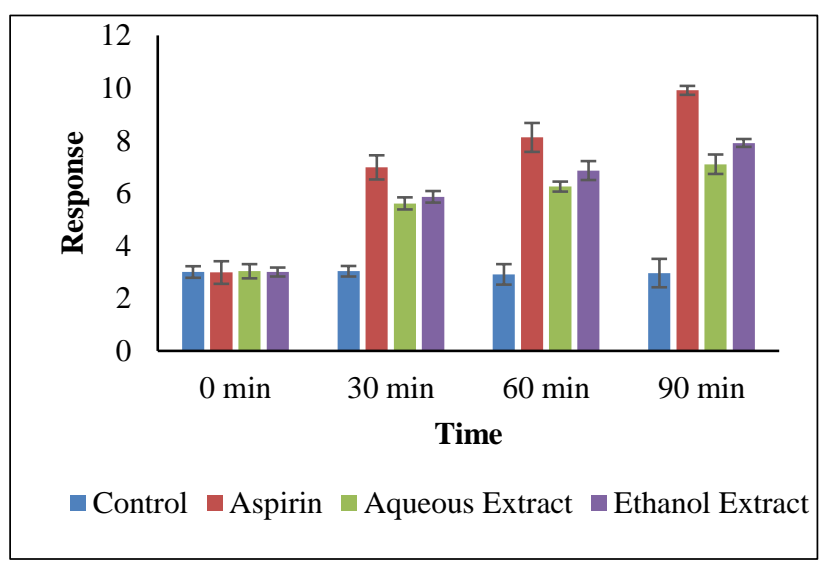

Figure 1: Variations in reaction times at different time intervals. 


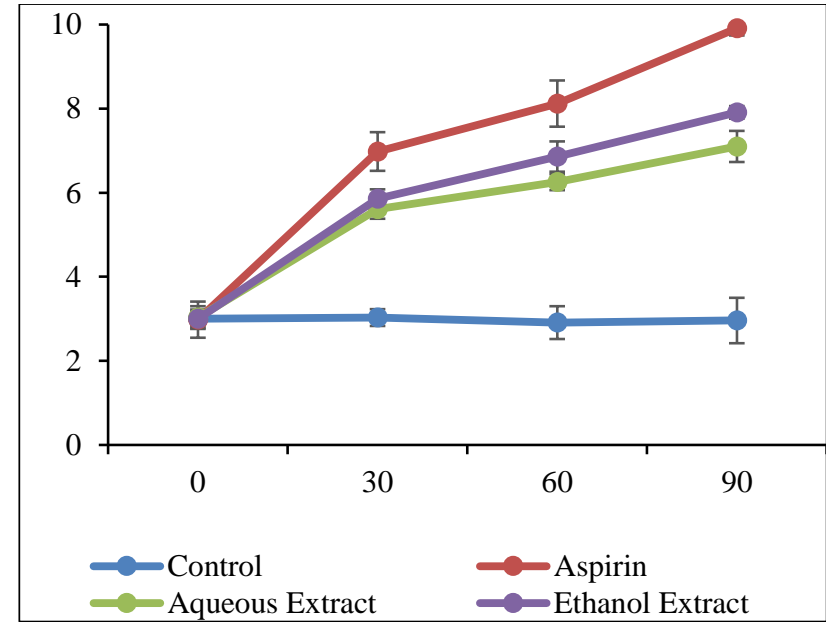

Figure 2: Variations in reaction times at different time intervals.

At 0min, all the groups didn't show any change. At 30min, all the groups showed increase in mean reaction time except control group. Standard drug showed the maximum effect and ethanolic extract showed slightly more response when compare to aqueous extract. At $60 \mathrm{~min}$, increased response when compare to $30 \mathrm{~min}$, was observed in test and standard groups. At 90min, maximum response was observed in standard group (aspirin). Ethanolic group showed significant increase when compare to aqueous group but it is not greater than the standard group. All these observations are showed in Figure 1 and Figure 2 with bar and line diagrams respectively.

In the present study, aqueous and ethanolic groups were compared for the analgesic activity. At 0min both groups showed no response. At 30,60 and 90min, mean reactions times were compared and it is observed that mice that were given ethanolic extract of Moringa leaves showed more response than aqueous group. All these observations are showed in Figure 3 and Figure 4 with bar and line diagrams respectively.

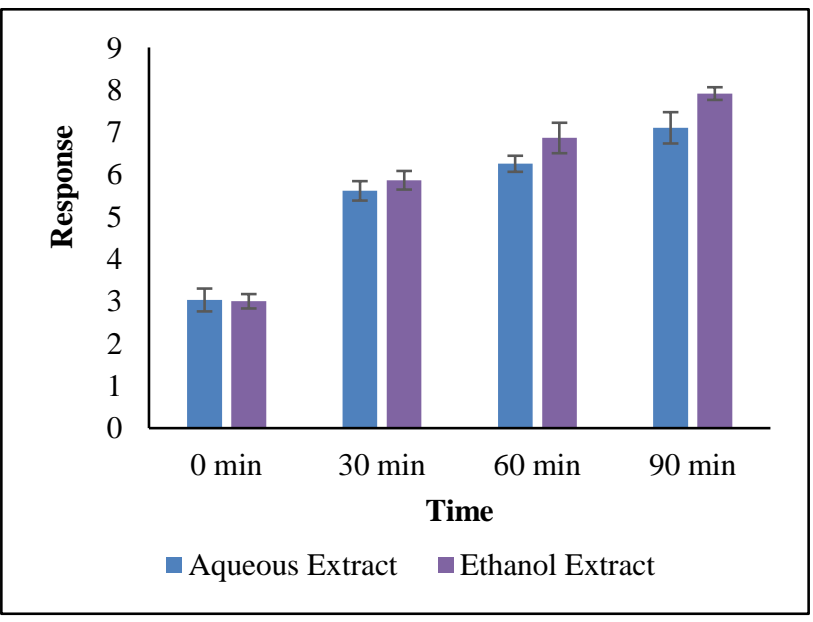

Figure 3: Comparison in reaction times of aqueous and ethanolic extracts at different time intervals.

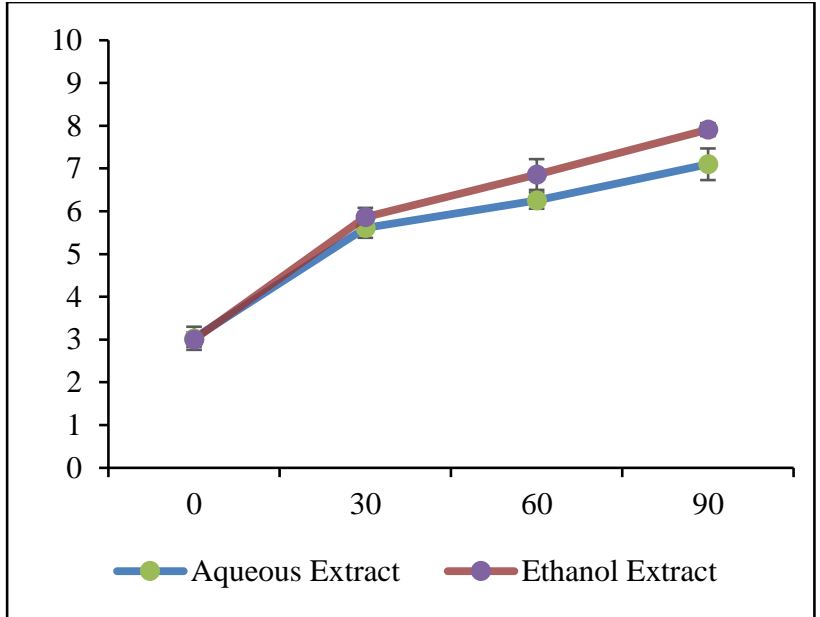

Figure 4: Comparison in reaction times of aqueous and ethanolic extracts at different time intervals.

\section{DISCUSSION}

Generally, several mechanisms of anti-nociception could be linked to the observed antinociceptive activity of leaf extracts of Moringa oleifera. Its diverse parts have been employed throughout history as food and medicine. The leaves of Moringa oleifera have been found to contain phenolics and flavonoids. ${ }^{6,7}$ Five major flavonoids like gallic acid, chlorogenic acid, rutin, quercetin, and kaempferol are identified in the leaf extracts. ${ }^{8}$

These compounds have various biological activities, including analgesic, anti-inflammatory, antioxidant, anticarcinogenic, immunomodulatory, antidiabetic, antiatherogenic, and hepatoprotective functions.

Several types of bio active compounds have been isolated from various parts of $M$. oleifera. Ethanolic extracts of $M$. oleifera leaves have been reported to contain various types of flavanol glycosides, as well as kaempferol, rutin, and quercetin. In earlier studies analgesic property of the seed extracts were reported. ${ }^{9}$ Based on the reported compounds isolated from $M$. oleifera leaves, several mechanisms of action related to those types of compounds could be used to explain the observed antinociceptive properties. ${ }^{10}$

Flavonoids have also been proposed to inhibit the proinflammatory activity of enzymes involved in free radical production, such as cyclooxygenase, lipoxygenase or inducible nitric oxide synthase. ${ }^{11}$

In earlier studies, analgesic effects of Moringa were proved in ethanolic extracts of leaves. ${ }^{12}$ In the present study, two types of Moringa leaf extracts were chosen for the present study and the nociceptive properties of aqueous and ethanolic extracts of Moringa oleifera were assessed in thermal (i.e., hot-plate test) model of nociception and compared with aspirin. The increase in the reaction time in response to a drug, denotes analgesic effect of the drug. And the results of the Hot plate method were expressed as 
mean \pm SD. The prolongation of the latency times of the standard and test solutions were compared to the values of the control group, and the percentage of increase in mean reaction time was statistically compared between test and standard drugs. The results were expressed as Mean \pm SD. Statistical analysis was done using One Way Analysis of Variance (ANOVA) followed by Dunnett's multiple comparison test. $\mathrm{P}<0.05$ was considered significant.

From the observations of ANOVA, it is understood that, when compared to control group, the standard and test groups showed significant $(\mathrm{p}<0.05)$ increase in the mean reaction time. This indicates that the standard, ethanolic and aqueous extracts of Moringa have analgesic property.

Standard, ethanolic and aqueous groups were compared with each other. $P$ values and statistical significance on comparison of reaction times between different groups using Dunnett's multiple comparison test were done. When the standard group was compared with the aqueous group, it was found to be significantly better $(\mathrm{p}<0.05)$. It indicates that, even though the aqueous extract, has analgesic property, it is not as effective as the standard drug at this dose. Ethanolic group showed almost similar response like standard group but not as effective as standard. In other studies, it was proved that, ethanolic extracts of moringa have more flavonoids and other chemical components when compare to aqueous extracts because of more solubility. ${ }^{13}$ In the present study mice treated with ethanolic extract showed statistically significant mean reaction time compare to aqueous group.

\section{CONCLUSION}

Earlier studies proved the presence of flavonoids, saponins, tannins in the leaf extracts of Moringa oleifera, which indicates the nociceptive activity of the Moringa oleifera. Only two types of extracts were used in the present study and future studies with other extracts like, petroleum ether, ethyl acetate, diethyl ether should be done to compare their efficacy with conventional analgesic drugs. In the present study, only one method is used. Further studies are essential to elucidate the detailed and other possible mechanisms of action for antinociceptive activities by using different analgesic models. Within the limitations of the present study it was found that aqueous and ethanolic leaf extracts of Moring oleifera possess antinociceptive activities. The plant has to be further explored for its phytochemical profile to identify the active constituent responsible for the above-mentioned activities.

Funding: No funding sources

Conflict of interest: None declared

Ethical approval: The study was approved by the Institutional Ethics Committee IDIAEC/Pharma/OMC/32/2016

\section{REFERENCES}

1. Bennett PN, Brown MJ. Clinical Pharmacology. 10th ed. 2007:293-307.

2. Linton S. Models of Pain Perception. Elsevier Health. 1st ed. $2005 ; 16$.

3. Shin JW, Seol IC, Son CG. Interpretation of animal dose and human equivalent dose for drug development. J Korean Oriental Med. 2010;31(3):1-7.

4. Upadhye K, Rangari V, Mathur V. Evaluation of antinociceptive activities of fresh leaf juice and ethanolic extract of Moringa oliefera Lamm. Asian J Pharm Clin Res. 2011;4:114-6.

5. Adedapo AA, Mogbojuri OM, Emikpe BO. Safety evaluations of the aqueous extract of the leaves of Moringa oleifera in rats. J Med Plant. 2009;3:586-91.

6. Mishra G, Singh P, Verma R, Kumar S, Srivastav S, Jha KK, Khosa RL. Traditional uses, phytochemistry and pharmacological properties of Moringa oleifera plant: An overview. Der Pharmacia Lettre. 2011;3(2):141-64.

7. Kumbhare M, Sivakumar T. Anti-inflammatory and analgesic activity of stem bark of Moringa oleifera. Pharmacologyonline. 2011;3:641-50.

8. Mensah JK, Ikhajiagbe B, Edema NE, Emokhor J. Phytochemical, nutritional and antibacterial properties of dried leaf powder of Moringa oleifera (Lam) from Edo Central Province, Nigeria. J Nat Prod Plant Res. 2012;2:107-12.

9. Sutar NG, Bonde CG, Patil VV, Narkhede SB, Patil AP, Kakade RT. Analgesic activity of seeds of Moringa oleifera Lam. Inter J Green Pharmacy (IJGP). 2008;2(2):108-10.

10. Sulaiman MR, Zakaria ZA, Bujarimin AS, Somchit MN, Israf DA, Moin S. Evaluation of Moringa oleifera aqueous extract for antinociceptive and antiInflammatory activities in animal models. Pharmaceutical Biology. 2008;46(12):838845.

11. Izzi V, Masuelli L, Tresoldi I, Sacchetti P, Modesti A, Galvano F, Bei R. The effects of dietary flavonoids on the regulation of redox inflammatory networks". Frontiers in Bioscience. 2012;17(7):2396-418.

12. Bhattacharya A, Agrawal D, Sahu PK, Kumar S, Mishra SS, Patnaik S. Analgesic effect of ethanolic leaf extract of moringa oleifera on albino mice. Indian $\mathrm{J}$ Pain. 2014;28:89-94.

13. Vongsak B, Sithisarn P, Mangmool S, Thongpraditchote $\mathrm{S}$, Wongkrajang $\mathrm{Y}$, et al. Maximizing total phenolics, total flavonoids contents and antioxidant activity of Moringa oleifera leaf extract by the appropriate extraction method Ind. Crops Prod. 2013;44:566-71.

Cite this article as: Patnaik PK, Majeed MA, Bhuvaneshwari, Kameswari L, Niharika MB. Comparative study of analgesic effect of Moringa oleifera leaf extracts with aspirin on experimental animals. Int J Basic Clin Pharmacol 2018;7:2096100. 